\title{
LOCAL WISDOM PRACTICES OF DAYAK INDIGENOUS PEOPLE IN THE MANAGEMENT OF TANA' ULEN IN THE KAYAN MENTARANG NATIONAL PARK OF MALINAU REGENCY, NORTH KALIMANTAN PROVINCE, INDONESIA
}

\author{
Anau Njau*, Doctoral student \\ Program of Environmental Science, Postgraduate School, University of Brawijaya, Indonesia
}

Hakim A., Lekson A.S., Setyowati E.

Postgraduate School, University of Brawijaya, Indonesia

*E-mail: hakimend61@gmail.com

\begin{abstract}
This study employed a qualitative approach to examine the local wisdom of indigenous peoples, specifically of the Dayak Kenyah indigenous people in the management of Tana' Ulen in the Kayan Mentarang National Park of Malinau Regency, North Kalimantan Province. The study included the practice of local wisdom in the management of Tana' Ulen in Kayan Mentarang National Park and the impact of local wisdom practices on deforestation. The local wisdom practices of the Dayak Kenyah indigenous people are arranged in customary rules and in the form of various ritual activities with the aim of maintaining the sustainability of Tana' Ulen and a balance between forest ecosystems with the social life of indigenous peoples. The impact of the local wisdom practices of the Dayak Kenyah indigenous people in the management of Tana' Ulen in the Kayan Mentarang National Park on forest destruction could be identified from the existence of forest utilization zones to limit forest use that may lead to massive forest destruction. In addition, forests are managed wisely under the customary law to improve the economy of the community by taking forest products sustainably under strict regulations of customary law and local wisdom practices.
\end{abstract}

\section{KEY WORDS}

Local wisdom, Tana' Ulen, Dayak Kenyah.

Culture and local wisdom are very closely related to society, meaning that everything is influenced by the culture of the community. Culture can be interpreted as a system of knowledge that includes systems of ideas or the ideas contained in the human mind so that in everyday life, the culture is abstract. While the embodiment of cultural objects is created by humans as being cultured, and the behavior of objects that are tangible, such as patterns of behavior, language, equipment life, social organization, religion, art, and such like, which all intended to help sustain life in human society.

Local wisdom refers to local knowledge (the invention of tradition), representing a set of actions or actions which are usually determined by acceptable rules and certain values and norms of behavior by repetition, which automatically implies continuity with the past. Empirically, indigenous peoples' beliefs manifested as local wisdom are able and effective to control human behavior that tends to control and exploit natural resources arbitrarily. In this regard, it is unwise to denounce and discredit the mindset and actions of indigenous peoples who consciously defend their values, religion, traditions, and norms of customary law to maintain the magical balance and social order of their community and the surrounding environment. We must appreciate and learn from the local wisdom of these indigenous people in the management of our nature and environment to make it more humane.

One manifestation of the local wisdom in natural resource management is the management of Tana' Ulen by the indigenous people of Dayak Kenyah in the village of Long Alango, Bahau Hulu District, Malinau Regency. Tana' Ulen in the language of the Dayak Kenyah people means an area that has been banned or has been imposed by someone's rights so other people must not enter the area. Physically, Tana' Ulen is a primary forest area 
along with certain watersheds that are rich in natural resources of high economic value to the local community and located not too far from the village. In the concept of Tana' Ulen, the river was originally a prohibited area for the community to freely catch fish; this was done to ensure the availability of fish and other preys during festive occasions or when guests were visiting the village. In addition, in the Tana' Ulen area, people are prohibited from cutting down trees, burning trees, opening fields, and carrying out other activities that cause forest destruction. Originally, Tana' Ulen was owned only by nobles in Long Alango, Long Uli, and Long Pujungan in Malinau Regency, North Kalimantan Province. The existence of Tana' Ulen in Long Alango represents the effort of the indigenous people to maintain environmental sustainability by imposing strict regulations in the utilization of forest products. The products that can be taken by the Dayak Kenyah people include gaharu (a kind of tree whose sap can be used for perfume), rattan, Kayu Wangi, fruits, fish, and animals. The indigenous people can use these forest products at certain times only and for public purposes. Personal consumption of forest products, such as fish, vegetables or animals, can be done yet in limited quantities.

In its journey, in 1980, the upstream area of the Kayan River up to the Mentarang River, covering an area of $1,360,500$ ha, was designated as a nature reserve based on the Decree of the Minister of Agriculture Number 847/Kpts/Um/II/1980. However, in 1990, DG PHPA in collaboration with WWF-Indonesia and LIPI prepared a management plan for the Kayan Mentarang area. A survey conducted by WWF and LIPI found a very high dependence of Dayak indigenous communities on forests. Thus, from 1992 to 1994, WWF and the Head of Pujungan District issued a recommendation that each village have Tana' Ulen and they proposed that Kayan Mentarang be converted into a National Park. This effort paid off on October 7, 1996, when the Kayan Mentarang Nature Reserve officially became the Kayan Mentarang National Park based on the Decree of the Minister of Forestry Number 631/ Kpts-/1996. This change has become a breath of fresh air for the Dayak indigenous people and for the existence of Tana' Ulen. Communities can stay in the area and utilize certain natural resources according to the regulations of Tana' Ulen in each village.

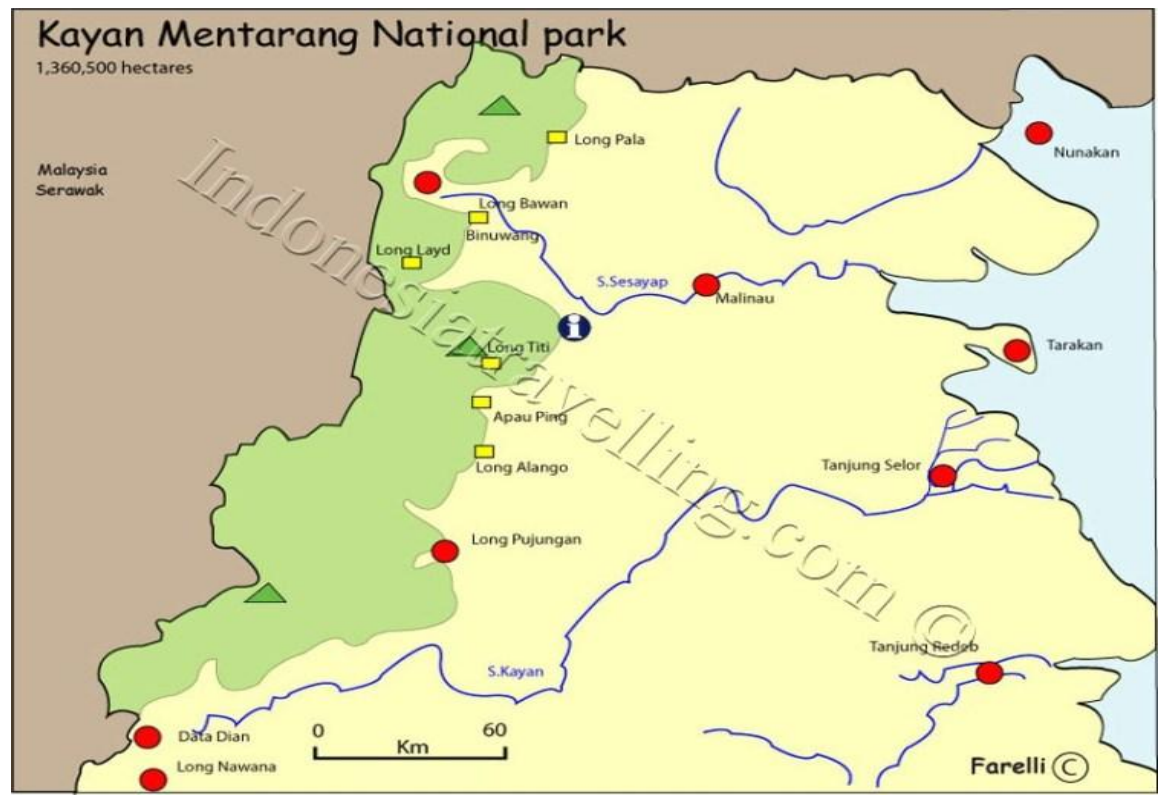

Figure 1 - The Map of the Kayan Mentarang National Park

In addition to the above regulations, there is also the Malinau Regional Regulation Number 4 of 2007 concerning Malinau as a Conservation Regency. This means that Malinau is a natural conservation area consisting of native ecosystems and/or unique ecosystems having characteristics in the form of diversity and/or uniqueness of species of plants and animals both on land and in waters, whose function is to protect life support systems, preserve biodiversity, and maintain sustainable use of biological natural resources and their 
ecosystems. In accordance with this definition, the Kayan Mentarang National Park is designated as a conservation area, whose function is to protect life support systems, preserve biodiversity, and maintain sustainable use of biological natural resources and their ecosystems. Based on this description, this study aims to describe and analyze the practice of local wisdom of the Dayak Kenyah indigenous people in the management of Tana' Ulen in the Kayan Mentarang National Park.

\section{THEORETICAL REVIEW}

Local wisdom is one manifestation of culture as a system that tends to preserve the tradition as a means to solve problems often faced by local communities in their daily life. In the context of the management of natural resources and the environment, the community manifests local wisdom in the form of conservation activities. Nababan and Suhartini (2009) put forward the principles of conservation of natural resource management traditionally as follows:

- Respect that encourages harmony in the relationship of human beings with the surrounding environment-in this case, traditional society tends to view itself as part of nature;

- An exclusive sense of belonging over a certain area or type of natural resource as communal property resource that it binds all people to maintain and secure this shared resource from outside parties;

- The local knowledge system, which gives the community the ability to solve the problems they face in utilizing limited natural resources;

- Adaptation power in the use of simple and appropriate technology that also saves energy in accordance with local natural conditions;

- The allocation system and enforcement of customary rules that can secure shared resources from excessive use, both by the community itself and by outsiders (migrants), through customary law institutions that regulate all aspects of community life in a particular social entity; and

- Equity mechanisms (distribution) of crops or shared resources that can prevent excessive gaps in traditional communities to occur, so there is no jealousy or social outrage or use of resources outside the applicable traditional rules.

Local wisdom is a term often used by scientists to represent a system of values and norms that are compiled, believed, and implemented by local communities based on their understanding and experience in synergy with the surrounding environment (Tjahjono et al., 1999; Prijono, 2000a; Prijono, 2000b).

According to Mitchell et al. (2000) and Soemarwoto (1999), local communities have developed an understanding of the ecological system in which they live. Human beings regulate the exploitation of the biophysical environment carefully through certain social laws based on empirical experience. Violations will result in sanctions, either from the community or from God. With this regulation, over-exploitation of the biophysical environment can be avoided such as exploitation of forest resources.

Local wisdom has a strong socio-cultural dimension, usually developing from human activities in life. Local wisdom is reflected in various forms, such as ideas, values, norms, and cultural conventions; in social life, it can be religious systems, social systems and organizations, knowledge systems, livelihood systems, and systems of technology and equipment (Koenjaraningrat, 2008). Literally, Echols and Syadily (2001) explain that local wisdom is a local idea of good values and prudence that can be followed by community members. Thus, local wisdom is a dynamic source of knowledge and it experiences continuous developments by certain populations in an integrated manner with an understanding of the surrounding culture and nature (Caroline Nyamai-Kisia, 2010).

Local communities have a very strong motive in maintaining their forests when compared to outsiders who tend to have other interests. Indigenous people who live on the outskirts of the forest and in the forest have to preserve the forest for the survival of the community as indigenous commodities. Two factors drive their motivation. First, it is related 
to the belief in the rights of origin inherited from generation to generation. Indigenous peoples are different from other community groups because they have original or traditional rights. Maintaining customary forests represents not only their concern on conservation but also actions in defending customary rights, inherited rights, and traditional rights passed down by their ancestors. Second, in addition to maintaining rights, indigenous people gain enormous benefits if their customary forests remain intact and are managed in a sustainable manner. Conversely, if there is damage to customary forests, by indigenous peoples or other parties, indigenous people are the party suffering the most (Nababan, 2002).

The view that humans are part of nature and a belief system that emphasizes respect for the environment according to Mithcell et al. (2000) is a very positive value for environmental preservation and the concept of sustainable forest resource management. Because people in forest areas, according to Sumardi (1997), still cling to their inherited traditional norms and, even though they are dependent on forests so much, it does not lead them to exploit forests on a large scale for commercial purposes. The indigenous communities see their forests as a sacred place of magical values that influence their cultural systems and social systems. Forests are considered not only as a physical environment but also to have their own spirits and these spirits protecting the forests may harm the surrounding communities shall they be treated badly (Tjahjono et al., 2000).

According to Law Number 41/1999 concerning Forestry, forests are an ecosystem in the form of landscapes containing biological resources of trees inseparable of their environment. These forests are grouped into several types, as follows. (1) A state forest refers to any forest on a land without a private land title. In other words, the state forest is the forest on public land. (2) A private forest refers to any forest situated on land with a title. (3) A customary forest is a state forest that is located in the territory of customary law communities. (4) A production forest is a forest area that functions to produce forest products. (5) A protected forest is a forest area that functions to protect the life support system, including to regulate the water system, to prevent floods, to control erosion, to prevent seawater intrusion, and to maintain soil fertility.

Many definitions have been put forward on Sustainable Forest Management (SFM). However, of all that, one universal definition is widely agreed upon between countries, i.e. the concept adopted by the United Nations Forum on Forests (UNFF) in December 2007. According to UNFF (2007) sustainable forest management is a dynamic and evolving concept that aims to maintain and enhance the economic, social, and environmental value of all types of forests, for the benefit of present and future generations.

Sustainable Forest Management has three characteristics, namely: (1) sustainability of production and forest service/benefits; (2) preservation of the physical environment of the forest (land, flora, fauna, hydrology, and climate); and (3) preservation of the social environment of the community (including social, economic and cultural) (Lindenmayer et al., 2000; Sheppard and Meitner, 2005; Siry et al., 2005; Kastanya, 2006). In more detail, UNFF (2007) explains seven (7) elements in sustainable forest management, namely (1) extent of forest resources, (2) forest biological diversity, (3) forest health and vitality, (4) productive functions of forest resources, (5) protective functions of forest resources, (6) socio-economic functions of forests, and (7) legal, policy, and institutional framework.

Forest management policies in Indonesia are changing, during the Old Order era, the New Order era, and the Reformation era. In the previous two orders, forest management was centralized, yet it was decentralized in the Reformation era. These policy changes directly affect the rate of deforestation and land degradation as well as rehabilitation programs. Nawir and Rumboko (2008) divided forest management policies in Indonesia over the past fifty years into four main periods with their respective priorities. The first period was from the 1950s to 1975 with the focus on expanding agriculture. The second was from 1975 to the 1990s with the focus on issuing Hak Pengusahaan Hutan (HPH) or Forest Concession Rights. The third period was from the 1990s to 1997, with the focus on forest management outside of the forest area. The last period was from 1998 to the present, a decentralized form of forest management in line with the enactment of the Regional Autonomy policy. 
Sustainable Forest Management is needed to prevent and lower deforestation. In general, cases of deforestation in Indonesia occur because the policies on forest management are centralized and exploitative, with the main focus to increase foreign exchange. As a result, almost half of Indonesia's forest area has been fragmented by road networks, other access routes, and various development activities, such as the construction of plantations and industrial plantations (Forest Watch Indonesia and Global Forest Watch, 2001) (Figure 2).

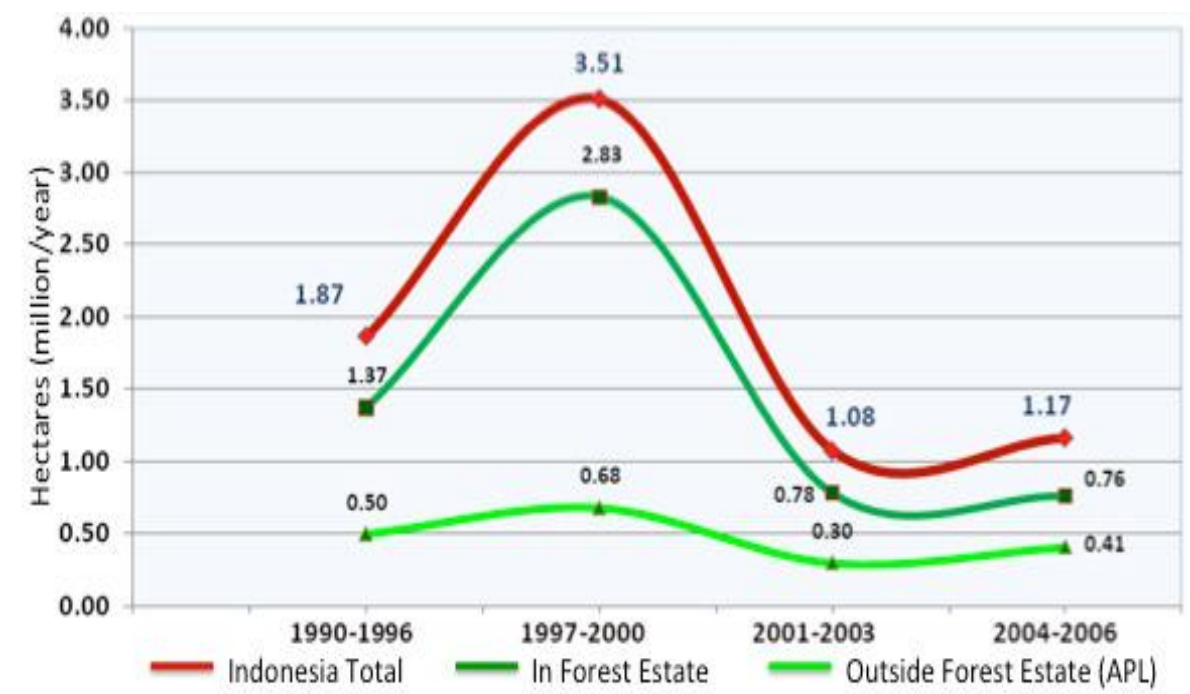

Figure 2 - The Rate of Deforestation in Indonesia (FAO, 2010; Dokumen Rencana Investasi Kehutanan Indonesia, 2012)

Table 1 - Deforestation and Degradation due to Planned and Unplanned Activities

\begin{tabular}{|c|c|c|}
\hline \multicolumn{2}{|c|}{ Sources of Greenhouse Gas Emissions } & Causes \\
\hline \multirow[t]{2}{*}{$\begin{array}{l}\text { Deforestation and } \\
\text { Forest Loss }\end{array}$} & Planned & $\begin{array}{l}\text { Expansion of administrative/regional government areas for infrastructure and } \\
\text { other needs } \\
\text { Lawful forest conversion (based on City Spatial Planning) } \\
\text { Forest conversion to land allocated for other purposes } \\
\text { Forest conversion for mining concessions (for example copper, gold, silver, } \\
\text { nickel, and tin) } \\
\text { Forest conversion for plantations (for example oil palm, rice fields, rubber, } \\
\text { coffee, and cacao) }\end{array}$ \\
\hline & Unplanned & $\begin{array}{l}\text { Illegal occupancy of forests for timber, firewood, agriculture, and small-scale } \\
\text { mining } \\
\text { Uncontrolled forest fires } \\
\text { Land ownership that causes conversion of forest areas }\end{array}$ \\
\hline \multirow[t]{3}{*}{ Forest Degradation } & Planned & $\begin{array}{l}\text { Persetujuan Izin Usaha Pemanfaatan Hasil Hutan Kayu Hutan Alam (IUPHHK- } \\
\text { HA) of Business Permit to Utilize Timber Forest Products in Natural Forest } \\
\text { Persetujuan Izin Usaha Pemanfaatan Hasil Hutan Kayu Hutan Tanaman Industri } \\
\text { (IUPHHK-HTI) or Business Permit for Primary Industry of Forest Products in } \\
\text { Industrial Plantation Forest }\end{array}$ \\
\hline & Unplanned & $\begin{array}{l}\text { Logging outside of allowable felling } \\
\text { Illegal logging } \\
\text { Small forest fires due to natural factors } \\
\text { Small forest fires for land clearing }\end{array}$ \\
\hline & Unplanned & $\begin{array}{l}\text { lllegal occupancy of forests for timber, firewood, agriculture, and small-scale } \\
\text { mining } \\
\text { Uncontrolled forest fires } \\
\text { Land ownership that causes conversion of forest areas }\end{array}$ \\
\hline \multirow[t]{2}{*}{ Forest Degradation } & Planned & $\begin{array}{l}\text { Persetujuan Izin Usaha Pemanfaatan Hasil Hutan Kayu Hutan Alam (IUPHHK- } \\
\text { HA) of Business Permit to Utilize Timber Forest Products in Natural Forest } \\
\text { Persetujuan Izin Usaha Pemanfaatan Hasil Hutan Kayu Hutan Tanaman Industri } \\
\text { (IUPHHK-HTI) or Business Permit for Primary Industry of Forest Products in } \\
\text { Industrial Plantation Forest }\end{array}$ \\
\hline & Unplanned & $\begin{array}{l}\text { Logging outside of allowable felling } \\
\text { lllegal logging } \\
\text { Small forest fires due to natural factors } \\
\text { Small forest fires for land clearing }\end{array}$ \\
\hline
\end{tabular}

Source: Good Practice Guidance for LULUCF (2003), in DRIKI (2012). 
Good Practice Guidance for LULUCF (2003) in DRIKI (2012) mentions the government of Indonesia distinguishes deforestation into planned and unplanned. The loss of areas taken from state-owned forests for non-forest land uses is considered planned deforestation. Deforestation and forest loss, as well as planned and unplanned land degradation, are shown in Table 1.

\section{CONCEPTUAL FRAMEWORK}

Empirically, indigenous peoples' beliefs manifested as local wisdom are able and effective to control human behavior that tends to control and exploit natural resources arbitrarily. In this regard, it is unwise to denounce and discredit the mindset and actions of indigenous peoples who consciously defend their values, religion, traditions, and norms of customary law to maintain the magical balance and social order of their community and the surrounding environment. We must appreciate and learn from the local wisdom of these indigenous people in the management of our nature and environment to make it more humane.

In accordance with the nobility of local wisdom of the indigenous people, the indigenous people of Dayak Kenyah in the village of Long Alango, Bahau Hulu District, Malinau Regency have preserved the principle of natural resource management for centuries, known as Tana' Ulen. Tana' Ulen in the language of the Dayak Kenyah people means an area that has been banned or has been imposed by someone's rights so other people must not enter the area. Physically, Tana' Ulen is a primary forest area along with certain watersheds that are rich in natural resources of high economic value to the local community and located not too far from the village.

Since 1980, the upstream area of the Kayan River up to the Mentarang River, covering an area of 1,360,500 ha, was designated as a nature reserve based on the Decree of the Minister of Agriculture Number 847/Kpts/Um/II/1980. This effort paid off on October 7, 1996, when the Kayan Mentarang Nature Reserve officially became the Kayan Mentarang National Park based on the Decree of the Minister of Forestry Number 631/Kpts-/1996. In addition to these regulations, there is also the Malinau Local Regulation Number 4 of 2007 concerning Malinau Regency as a Conservation Regency.

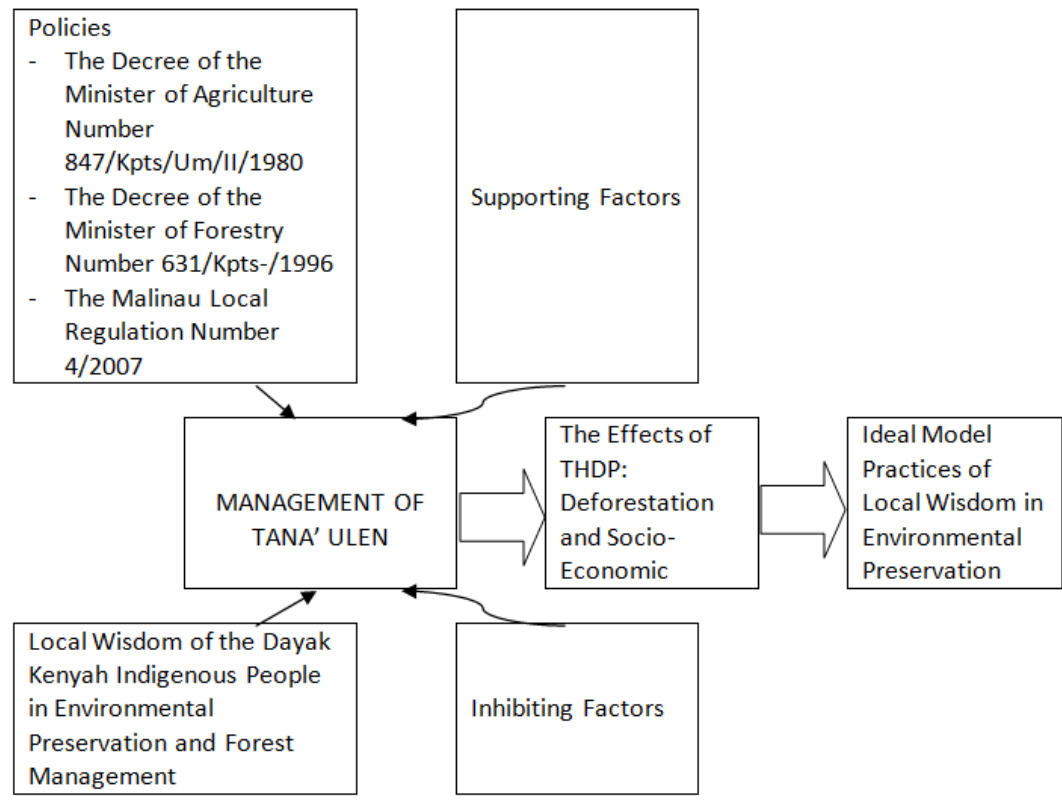

Figure 3 - Conceptual Framework

Land management in the Kayan Mentarang National Park cannot be separated from the role of several parties. The government of North Kalimantan Province is committed to 
respect, protect, and preserve the values and cultural practices of indigenous tribes living around the Kayan Mentarang National Park in North Kalimantan. Only one regional government, i.e. Malinau Regency, in the Province of North Kalimantan has a regional regulation on the protection of territories and indigenous people so far. Aside from the government's role in environmental conservation in the Kayan Mentarang National Park, Non-Government Organizations (NGOs), such as WWF Indonesia, also collaborate with stakeholders, namely the Ministry of Forestry through the Directorate General of Forest Protection and Nature Conservation, local government, local communities and International Institutions, to utilize important assets and at the same time to find new models in the management of the National Park.

In the management of Tana' Ulen as local wisdom in conservation activities, there are supporting and inhibiting factors. Through a qualitative study, the researchers identified these factors to create a (qualitative) model of local wisdom practices that can preserve the environment.

\section{METHODS OF RESEARCH}

This study involved local wisdom of indigenous peoples, especially the Dayak Kenyah indigenous people in the management of Tana' Ulen in the Kayan Mentarang National Park, Malinau Regency, North Kalimantan Province. The study included practices of local wisdom in the management of Tana Ulen in Kayan Mentarang National Park and the impact of such practices on deforestation.

This study employed a qualitative approach aiming at describing comprehensively the object studied in the Dayak Kenyah indigenous community and specifically the communities living around the Kayan Mentarang National Park. The collected data were tested for validity and reliability using credibility tests (internal validity), transferability (external validity), dependability (reliability), and confirmability (objectivity). Then the data was analyzed using the Interactive Model method (Miles et al., 2014), with a data analysis component consisting of data collection, data condensation, data display, and conclusions. The interactive model in data analysis is shown below.

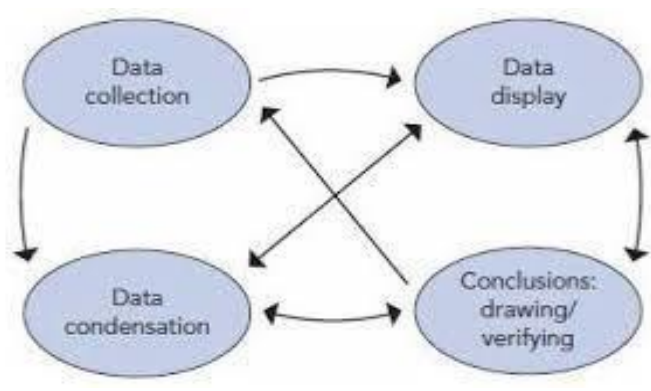

Figure 4 - Components of Data Analysis: Interactive Model (Source: Matthew B. Miles et al., Qualitative Data Analysis: A Methods Sourcebook. Singapore: SAGE Publications Inc., 2014:33)

\section{RESULTS AND DISCUSSION}

Local Wisdom Practices of Dayak Kenyah Indigenous Peoples in the Management of Tana' Ulen in the Kayan Mentarang National Park. Among the Dayak Kenyah indigenous people, the practice of local wisdom is manifested in the management of Tana' Ulen in the Kayan Mentarang National Park. The practice includes customary rules, activities to preserve forests, and utilization of Tana' Ulen forest products. Local people have certain rules for generations and the rules are still practiced these days. One customary rule that applies is that indigenous people are permitted to utilize forest products from Tana' Ulen for certain events such as Thanksgiving or weddings. However, it can only be done once a year.

Tana' Ulen as a protected area has certain strict regulations. Violations will bring sanctions and fines, such as paying with jars (tempayan), gongs, decorative machetes (baing 
sua), or money, and confiscation of tools and goods as the results of violations. Another rule applied is that utilization forest products from Tana' Ulen must be upon permission from the Village Head and Customary Head. The customary regulations of the Dayak Kenyah indigenous people also apply to communities outside of the Dayak Kenyah. The regulation is related to the prohibition of outsiders to enter and take forest products of Tana' Ulen; violations will result in certain sanctions imposed in accordance with the Customary Rules.

The existence of various rules represents local wisdom as one of the cultural investments in local communities. Koenjaraningrat (2008) writes that Local wisdom can be reflected in various forms, such as ideas, values, norms, and cultural conventions; in social life, it can be religious systems, social systems and organizations, knowledge systems, livelihood systems, and systems of technology and equipment. The indigenous communities see their forests as a sacred place of magical values that influence their cultural systems and social systems. Forests are considered not only as a physical environment but also to have their own spirits and these spirits protecting the forests may harm the surrounding communities shall they be treated badly (Tjahjono et al., 2000).

The Dayak Kenyah people basically maintain Tana' Ulen through their local wisdom to preserve forests. Because people in forest areas, according to Sumardi (1997), still cling to their inherited traditional norms and, even though they are dependent on forests so much, it does not lead them to exploit forests on a large scale for commercial purposes.

Local people around Kayan Mentarang National Park are also directly involved in management-they are inseparable of the management of the National Park because they have a stronger inner bond compared to outsiders in general. This inner bond arises because of the association of local communities with their ancestral lands. Nababan (2002) states local communities are different from other community groups because they have traditional or customary rights. Maintaining customary forests represents not only their concern on conservation but also actions in defending customary rights, inherited rights, and traditional rights passed down by their ancestors.

Based on the description, it can be concluded that if the customary rules of the Dayak Kenyah indigenous people are still preserved, then the customary rules related to forest management can also be preserved as part of sustainable development.

Activities Related to the Protection of Tana' Ulen. In the management of Tana Ulen, the Dayak Kenyah indigenous people have some activities like the prohibition for other communities to enter protected forest areas. The prohibition is marked with a sign (SIP) of parang or Mandau made of wood mounted on certain trees in Tana' Ulen for people to easily see the sign and remember that the area is protected. The Dayak Kenyah indigenous people do this to maintain the integrity of the protected area by prioritizing their local wisdom. Related to this, Mitchell et al. (2000) and Soemarwoto (1999) state local communities have developed an understanding of the ecological system in which they live.

Another activity to protect Tana' Ulen is the prohibition of activities that can damage forest sustainability. This is in line with the Regulation Number 32/2009 concerning the purpose of environmental protection and management. The objectives are (1) to protect the territory of the Republic of Indonesia from pollution and/or environmental damage; (2) to guarantee safety, health, and human life; (3) to guarantee survival guarantee the survival of living things and ecosystem sustainability; (4) to maintain the preservation of environmental functions; (5) to achieve harmony and environmental balance; (6) to guarantee justice for present and future generations; (7) to guarantee the fulfillment and protection of environmental rights as part of human rights; (8) to control the use of natural resources; (9) to realize sustainable development; and (10) to anticipate global environmental issues.

Based on the description, it can be concluded that if indigenous people keep protecting Tana' Ulen continuously, they will be able to preserve the forests without overruling the ancestral beliefs.

Utilization of Forest Products in the Kayan Mentarang National Park. The utilization of forest products from the Kayan Mentarang National Park is carried out according to the needs of the Dayak Kenyah indigenous people-this ensures that they get benefits from forest products based on prevailing customary regulations. The Dayak Kenyah people use 
forest products such as rattan, black honey, wood, and others. Indigenous people have known and utilized forest products in their daily life for generations in accordance with customary law. Sumanto and Mariana (2014) confirm that there is close social interaction and interdependence between indigenous Dayak Kenyah people with their environments in which they take the forest products and at the same time maintain the sustainability of natural resources.

Based on the discussion, the following proposition can be formulated: if customary rules and traditional activities are carried out continuously, the use of forest products will be beneficial for the welfare of the community and can create a sustainable environment.

The Impact of Local Wisdom Practices of Dayak Kenyah Indigenous People in the Management of Tana' Ulen in the Kayan Mentarang National Park on Forest Conservation. The local wisdom practiced by the indigenous people in managing Tana' Ulen in the Kayan Mentarang National Park aims at preserving the forests. This shows efforts to manage natural resources and the environment as a manifestation of forest conservation by the community. In this regard, Suhartini (2009) put forward the principles of conservation of natural resource management traditionally as follows:

- Respect that encourages harmony in the relationship of human beings with the surrounding environment-in this case, traditional society tends to view itself as part of nature;

- An exclusive sense of belonging over a certain area or type of natural resource as communal property resource that it binds all people to maintain and secure this shared resource from outside parties;

- The local knowledge system, which gives the community the ability to solve the problems they face in utilizing limited natural resources;

- Adaptation power in the use of simple and appropriate technology that also saves energy in accordance with local natural conditions;

- The allocation system and enforcement of customary rules that can secure shared resources from excessive use, both by the community itself and by outsiders (migrants), through customary law institutions that regulate all aspects of community life in a particular social entity; and

- Equity mechanisms (distribution) of crops or shared resources that can prevent excessive gaps in traditional communities to occur, so there is no jealousy or social outrage or use of resources outside the applicable traditional rules.

Local wisdom in the Dayak Kenyah indigenous people is realized in the form of (1) utilization of natural resources, like gaharu, rattan, cinnamon, fruits, and preys, must get permission from the Customary Head; and (2) prohibitions in hunting, which can damage the sustainability of the National Park. Local wisdom has an impact on the welfare of the surrounding community. The forests can fulfill water needs for rice fields as part of the sustainability of livelihoods of the local community and fulfill the needs of wood construction materials for settlement. Therefore, the local wisdom of the Dayak Kenyah indigenous people in forest management must be preserved as an effort to maintain the sustainability of livelihoods and building materials.

Based on the discussion, the following proposition can be formulated: wisdom rooted strongly for generations and carried out with a high commitment to conservation and economy will help to balance the ecological and economic functions of the forest.

Forest Sustainability and Efforts to Overcome Impacts on Local Community SocioEconomic Conditions, Especially Those Living around the National Park. According to UNFF (2007), sustainable forest management is a dynamic and evolving concept that aims to maintain and enhance the economic, social, and environmental value of all types of forests, for the benefit of present and future generations. The existence of Tana' Ulen forests also increases economic, social, and environmental values. Economically, forests help to improve the economy of the surrounding community, in which forest products can meet the needs of the local community and the small amount of it can be sold. From a social standpoint, harmony, cooperation, and mutual respect exist among the indigenous people. Furthermore, Tana' Ulen is an educational object, both for Indonesian citizens and foreigners. 
In its development, Tana' Ulen provides a new paradigm of forest management, i.e. taking benefits from forests without destroying forests. Violations of the rules in the management of Tana' Ulen will result in sanctions from the community and from God. The presence of outsiders into the Tana' Ulen forest area has raised concern for the people around the forest since they are worried about the sustainability of indigenous culture preserved so far. Therefore, certain efforts need to be made to overcome the problem. Sustainable Forest Management has three characteristics, namely: (1) sustainability of production and forest service/benefits; (2) preservation of the physical environment of the forest (land, flora, fauna, hydrology, and climate); and (3) preservation of the social environment of the community (including social, economic and cultural) (Lindenmayer et al., 2000; Sheppard and Meitner, 2005; Siry et al., 2005; Kastanya, 2006).

The efforts to overcome the impact on the socio-economic conditions of the local community, especially those living and living around the Kayan Mentarang National Park, referring to the opinions above, are as follows: (1) conducting training related to the environment, including knowledge related to protected animals; (2) conducting training for forest guides to become more reliable, professional, and competent guides by combining local and modern safety techniques; (3) providing foreign language courses, which are indispensable to explain the local language or traditions and customs around Tana' Ulen; (4) opening workshops of traditions such as local art, dance, and music, to introduce local culture to the younger generation; and (5) community economic empowerment training especially for indigenous women, such as making handicrafts typical of Tana' Ulen.

Based on the discussion, the following proposition can be formulated: if the impact of local wisdom practices in managing Tana' Ulen can be properly addressed, then the socioeconomic conditions of the local community can be elevated and the culture can be preserved to ensure sustainable forest management.

\section{CONCLUSION AND RECOMMENDATIONS}

Local wisdom practices of the Dayak Kenyah indigenous people in the management of Tana' Ulen in the Kayan Mentarang National Park include customary rules and activities related to the utilization of forest products. To the present, the customary rules in Tana' Ulen are well maintained. As an example, the community is prohibited from cutting down trees, opening fields, burning fields, and other activities that could damage the forests. On certain occasions, people are allowed to take the forest products, such as in the celebration of harvest, wedding, childbirth, or other special events in the village. The indigenous people also protect their forests from outsiders by mounting parang or Mandau, as SIP signs, on trees as a reminder that the area is protected.

The impact of the local wisdom practices of the Dayak Kenyah indigenous people in the management of Tana' Ulen in the Kayan Mentarang National Park on forest destruction can be identified as follows. (a) There is a zoning system in forest management based on local wisdom. The zoning system aims to limit the exploitation of forests that massive deforestation can be avoided. Besides that, the local wisdom has also strengthened the role of the forest in fulfilling the water needs for rice fields and the needs of wood for construction materials to build settlements. (b) Tana Ulen can function as a barn for the village in which the potential of the forest can provide a sense of security and guarantee for the survival of the community both economically and socially. Thus, the forest is managed wisely to improve the economy of the community by taking forest products sustainably under strict regulations of customary law and the practice of local wisdom.

\section{REFERENCES}

1. Dennis, R. A., \& Colfer, C. P., 2006. "Impacts of land use and fire on the loss and degradation of lowland forest in 1983-2000 in East Kutai District, East Kalimantan, Indonesia". In Singapore Journal of Tropical Geography, 27(1), 30-48. 
2. Dokumen Rencana Investasi Kehutanan Indonesia (DRIKI), 2012. Program Investasi Kehutanan: Rencana Investasi Kehutanan Indonesia. Jakarta: Departemen Kehutanan Indonesia.

3. Engel, S., \& Palmer, C., 2006. "Who owns the right? The determinants of community benefits from logging in Indonesia". In Forest Policy and Economics, 8(4), 434-446.

4. FAO, 2010. Global forest resources assessment 2010: Main report. Hutan untuk pelestarian. Jakarta: Bumi Aksara.

5. Forest Watch Indonesia \& Global Forest Watch, 2001. Keadaan Hutan Indonesia. Bogor, Indonesia: Forest Watch Indonesia and Washington D.C.: Global Forest Watch.

6. Fox, J., \& Vogler, J. B., 2005. "Land-use and land-cover change in montane mainland Southeast Asia". In Environmental Management, 36(3), 394-403.

7. Fuller, D. O., Jessup, T. C., \& Salim, A., 2004. "Loss of forest cover in Kalimantan, Indonesia, since the 1997-1998 El Nino". Conservation Biology, 18(1), 249-254.

8. Ginoga, K., Lugina, M., \& Djaenudin, D., 2005. "Kajian Kebijakan Pengelolaan Hutan Lindung". Dalam Jurnal Penelitian Sosial and Ekonomi Kehutanan, 2(2), 203-231.

9. Gray, G. J., Enzer, M. J., \& Kusel, J., 2001. "Understanding community-based forest ecosystem management: an editorial synthesis". In Journal of Sustainable Forestry, 12(34), 1-23.

10. Griffiths, T., 2004. "Indigenous peoples, land tenure and land policy in Latin America". In Land Reform, Land Settlement and Cooperatives, 1, 46-63.

11. Hasbiah, Astri, 2015. "Analysis of Local Wisdom As An Environmental Conservation Strategy In Indonesia". In Journal Sampurasun: Interdisciplinary Studies for Cultural Heritage, Sampurasun e-Journal Vol 01, No. 01. December 2015.

12. Hunt, C., 2010. "The costs of reducing deforestation in Indonesia". In Bulletin of Indonesian Economic Studies, 46(2), 187-192.

13. Jayadi, Edi Muhammad; and Soemarno; and Yanuwiadi, Yanuwiadi; and Purnomo, Mangku; 2014. "Local Wisdom Transformation of Wetu Telu Community on Bayan Forest Management, North Lombok, West Nusa Tenggara". In Research on Humanities and Social Sciences, ISSN 2222-1719 (Paper) ISSN 2222-2863 (Online), Vol.4, No.2, 2014.

14. Lestari, Sri; and Kotani, Koji; and Kakinaka, Makoto; 2014. "Enhancing Voluntary Participation In Community Collaborative Forest Management: A case of Central Java, Indonesia". In Journal of Environmental Management, 150 (2015) 299e309, Oct.2014.

15. Li, M.T., 2007. "Practices of assemblage and community forest management". In Economy and society, 36(2), 263-293.

16. Miles, Matthew B.; and A. Michael Huberman; and Johnny Saldana; 2014. Qualitative Data Analysis: A Methods of Sourcebook. Singapore: Sage Publications Inc.

17. Muhammadi; and Aminullah, Erman; and Soesilo Budhi; 2001. Analisis Sistem Dinamis: Lingkungan Hidup, Sosial, Ekonomi, Manajemen. Jakarta: UMJ Press.

18. Mitchell, B., 2000. Pengelolaan Sumber Daya Lingkungan. Yogyakarta: Gadjah Mada University Press.

19. Miettinen, J., Shi, C., \& Liew, S. C., 2011. "Deforestation rates in insular Southeast Asia between 2000 and 2010". In Global Change Biology, 17(7), 2261-2270.

20. Nanang, Martinus; and Inoue, Makoto; 2000. "Local Forest Management in Indonesia: A Contradiction Between National Forest Policy and Reality". In International Review for Environmental Strategies, Vol.1, No.1, pp. 175 - 191, 2000.

21. Nawir \& A. Adiwinata, 2008. "Rehabilitasi Hutan di Indonesia: Akan kemanakah arahnya setelah lebih dari tiga dasawarsa?”. dalam Nawir, A. A., \& Rumboko, L. (eds.), Sejarah and Kondisi Deforestasi and Degradasi Lahan. Bogor, Indonesia: Center for International Forestry Research (CIFOR).

22. Nawir, A. A., Murniati, Rumboko, L., Hiyama, C., \& Gumartini, T., 2008. "Potret Rehabilitasi di Indonesia". Dalam Nawir \& A. Adiwinata (eds.), Sejarah and Kondisi Deforestasi and Degradasi Lahan. Bogor, Indonesia: Center for International Forestry Research (CIFOR). 
23. Nyamai-Kisia, C., 2010. "Kearifan Lokal and Pembnangunan Indonesia". Diakses melalui http:// phenomenaaroundus. blogspot. com / 2010 / 06 /kearifan - lokal - danpembangunan.html.

24. Perum Perhutani, 2007. Pengelolaan Hutan Bersama Masyarakat (PHBM): Kolaborasi antara Masyarakat Desa Hutan dengan Perum Perhutani dalam Pengelolaan Sumberdaya Hutan di Jawa. Dokumen yang disusun sebagai media sosialisasi LMDH dalam kerangka Levelling the Playing Field Project, yang didanai oleh Uni Eropa, bekerjasama dengan CIRAD, CIFOR, Fakultas Kehutanan UGM and Perum Perhutani. p. 4.

25. Perum Perhutani, 2007. "Tingkat partisipasi petani hutan dalam program pengelolaan hutan bersama masyarakat (PHBM) Perhutani”. Dalam MIMBAR, 28(1), 65-76.

26. Primyastanto, Mimit, 2014. "Fisheries Resource Management through Local Institutions in Empowering Community Based on Local Wisdom in Coastal Madura Strait". In International Review of Social Sciences, Vol. 2 Issue.5, 2014.

27. Ruhimat, I. S., 2010. "Implementasi Kebijakan Kesatuan Pengelolaan Hutan (KPH) di Kabupaten Banjar". In Jurnal Analisis Kebijakan Kehutanan, 7(3), 169-178.

28. Riniwati, Harahab and Abidin. 2016. Loss Estimation of Protected Forest Damage and Its Impact on Fishery Sector in Goa Cina Beach, Sout Area of Malang Regency. WacanaVol 19, No. 3 (2016) ISSN : 0199 E-ISSN : 2338-1884.

29. Siscawati, M., 2014. "Masyarakat Adat and Perebutan Penguasaan Hutan". Dalam Wacana: Jurnal Transformasi Sosial, 33, 3-23.

30. Soemarwotto, O., 1999. Analisis Mengenai Dampak Lingkungan Hidup. Yogyakarta: Gadjah Mada University Press

31. Otto, Soemarwoto, 2004. Buku Ekologi Lingkungan Hidup and Pembangunan. Jakarta: Djambatan.

32. Suhartini, 2009. "Kajian Kearifan lokal masyarakat dalam pengelolaan sumberdaya alam and lingkungan". Jurusan Pendidikan Biologi FMIPA Universitas Negeri Yogyakarta. Journal penelitian.

33. Suprayitno, A. R., 2008. "Pelibatan Masyarakat Lokal: Upaya Memberdayakan Masyarakat Menuju Hutan Lestari”. Dalam Kajian Analitik, Jurnal Penyuluhan,4 (20), 2028.

34. Tamalene, M. Nasir; and Al Muhdhar, Mimien Henie Irawati; and Suarsini, Endang; and Rochman, Fatkhur Rochman; 2014. "The Practice of Local Wisdom of Tobelo Dalam (Togutil) Tribal Community in Forest Conservation in Halmahera, Indonesia". In International Journal of Plant Research 2014, 4(4A): 1-7 DOI: 10.5923/s.plant.201401.01.

35. Thorburn, C., 2002. "Regime change--prospects for community-based resource management in post-New Order Indonesia". In Society \& Natural Resources, 15(7), 617628.

36. Undang-Undang Nomor 32 Tahun 2009 tentang Perlindungan and Pengelolaan

37. Winata, A. and Yuliana, E., 2012. "Tingkat Partisipasi Petani Hutan dalam Program Pengelolaan Hutan Bersama Masyarakat (PHBM) Perhutani”. Dalam Jurnal Sosial and Pembangunan 28 (1).

38. Wollenberg, E., Moeliono, M., Limberg, G., Iwan, R., Rhee, S., \& Sudana, M., 2006. "Between state and society: local governance of forests in Malinau, Indonesia". In Forest Policy and Economics, 8(4), 421-433. 